\title{
18. 除草剂による薬害の解析
}

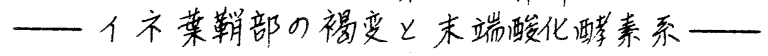

$$
\text { 楖井功. 中材弘(日本農薬・研) }
$$

除草剂によつフ生びるイネの菜鞘部褐变は、著しい場合には生育抑制となつフ現《

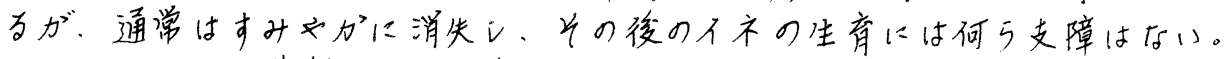

こガ、、この莱䩗部褐变も薬害である以上、剂の適用に際しては、褐变の性貨を十

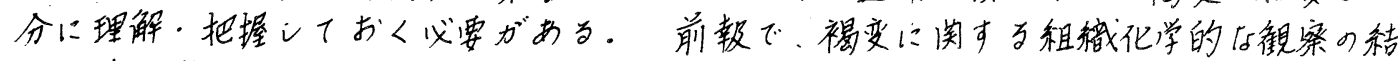
果、午の発現には、1、光ガ必須の要因である乙と、2)、最外側の莱鞘部の山に褐变

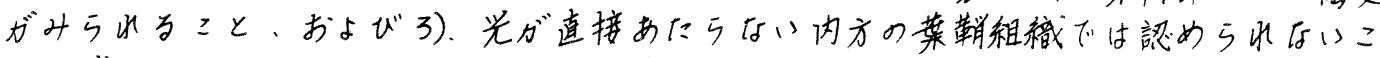
とを述べた。っ、では、更に光との腱において得られた若平の知見にフいて報告 iたい。

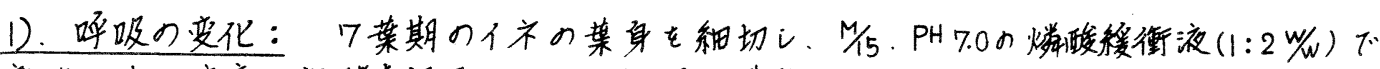

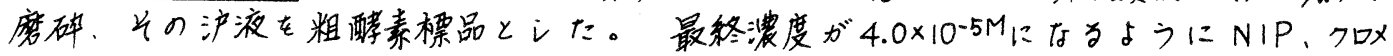
トキシニルおよびフェノピレートを加え、32ㄷ、暗条件および4,000Luxの明条件下で呼吸量 を調べた結果(为!表)、特に明条件下で著しい $\mathrm{CO}_{2}$ 排出量の增加が訯めら水、末端酸化 醋素系に变動のあることが示唆それた。

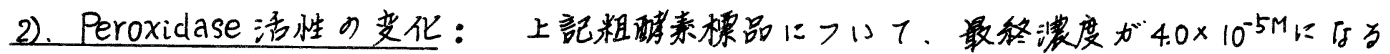

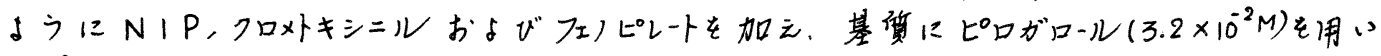

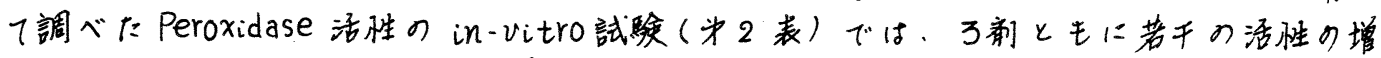

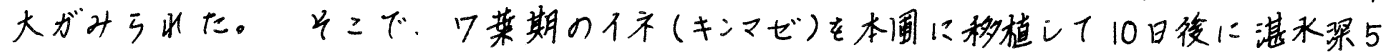

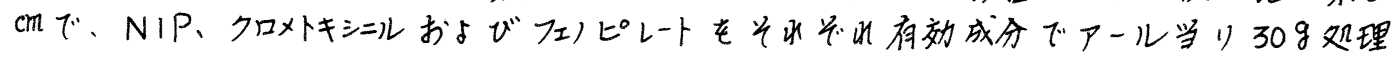
レ、イネのPeroxidase活性の变化をWillstäter'stoll のPurProgalin法によつ1圣 日的に調ベたところ(为四)、イネの菜䩴部においては、万剂ともに同妳の消長を示し 処理直後より若千活性の增大がタられ、2日目に著しい活性の增加を認め下。长 の後、5日目には、活性がガえって低下ンたが、処理10日目頃には回復していた。

一方、莱身部おむび抽出菜部では、処理道後に若干活性の增大ガみらルだのみであ $\neg た 。$

3). Indole Acetic Acid Oxidase 活性の变化：ジフェニルエーテル 系除草剂では、イネ

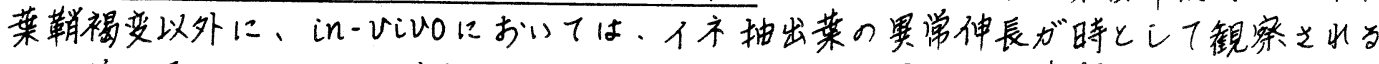
。 毛こで、NIP、クロメトキシニルおよU゙フェル゚レートを用い、6菜期のイネ(キンマゼ)で

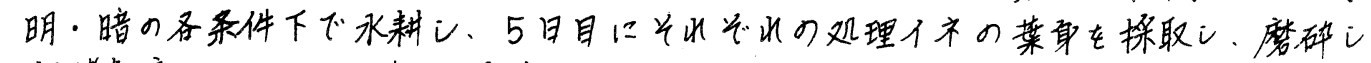
た粗䤀素液のI・A.A Oxidase活性をGortner \& Kentの方法下测定した(为了表)。

了剂の処理イネともに、明・暗の各条件を问わずI・A・A Oxidase活性は增大に、殊 に、NIP、クロメトキシニルに比しフェルピレートで大娄い。 I·A-A Oxidasen活性につ1) ては、圣日的には調べていないが、処理5日目における Peroxidase活性の低下カう この時期における长の增大も理由ブけられる。 
4). Peroxidase isozyme: 7菜期のイネ(キンマゼ)をポットに移植し.10日目に湛我深

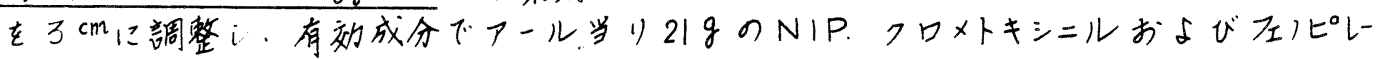
卜を施用して、1 日目に採取しにイネ菜䩗部のホモジネートにフいてザイモグラフを フくフた。各々のアイソザイムの数はおよ羊10で、㦈基性侧に4、酸性侧に5〜 6 で、特異『アイソザイム・バンドは認められたかった。また、発色の強さが無処 理に比較し1相対的に活性の增大ガ認められた。

5). 褐变と光との荓係：1/6.000アールポットにワ莱期のイネ(キンマぜ)を移植し、莱䩗

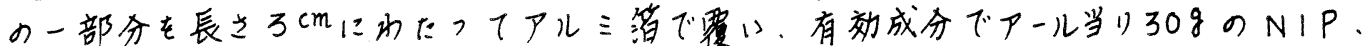
クロメトキシニルおよびフェル゚レートを処理え、5日目に採取レイ褐变の発理状況、0-diph - e nol量をARNOWの方法で测定した。广の結果、裼变は懪光している菜䩗部のみに認 カラれ、アルミ谄で遮光した莱鞘部位には全く認められなカった。更に了剂とも、 懪光により裼变した部位下゙は、アルミ簿で遮光レた褐变の認のられたい部位よりもの -diphenol量は增大ンイおり(勿4表)、生体内で生成される通酸化物の珄生に光が仪要で あることを示唆している。

6).褐变の発現消長と体内0-diphenol量の推移：17莱期のイネ(キンマゼ）を1/6,000ア

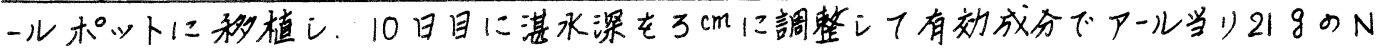

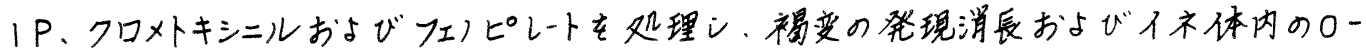

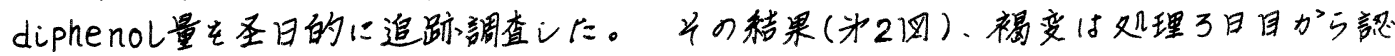

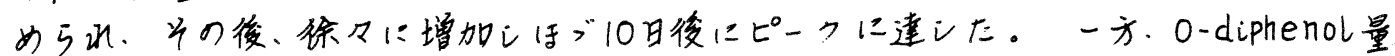

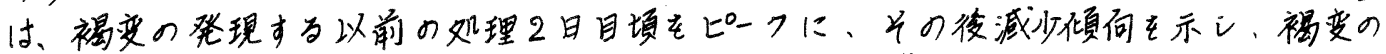
最大に達する观理10日目垻には。ほブ刑処理イネと同等となった。

7)、まとめ: 褐变は、肉眼的には通常、処理了日目垻より認められるが、年れ以前 に0-diphenol 量のピークガ末端酸化醉䒺系の一Oxidase 系でのるPeroxidase活性の增加と ともに平行えて認められ、殊に光条件下ドこれらの瑅象が影著であった。更に褐变 の增大にフれ1、体内の0-diphenol量は減少し、褐变の落ち着く時期には0-diphenol 量も、ほづ無処理に古をることを認めた。

これらのことは、褐变が薬刘に対する一生物防禦的反心であり、一時的たものであ るのガもしれほい。

为卜表: 明・暗条件下における呼吸

\begin{tabular}{|c|c|c|c|c|c|}
\hline 17 & 菜 & $\begin{array}{c}\mathrm{O}_{2} \text { 吸收量 } \\
\mu l / 1.0^{8 \mathrm{~F} \cdot W / \mathrm{hrs}}(\%)\end{array}$ & $\begin{array}{l}\mathrm{CO}_{2} \text { 排出量 } \\
\mu l / 1.0^{8} \mathrm{~F} \cdot \mathrm{W} / \mathrm{hrs}\end{array}$ & $s(\%)$ & $R \cdot Q$ \\
\hline 明 & 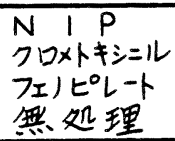 & $\begin{array}{r}115.50(123) \\
103.50(110) \\
109.77(117) \\
94.05(100)\end{array}$ & $\begin{array}{r}210.65 \\
175.67 \\
204.75 \\
96.67 \\
\end{array}$ & $\begin{array}{l}(218) \\
(182) \\
(212) \\
(100)\end{array}$ & $\begin{array}{l}1.82 \\
1.69 \\
1.85 \\
1.02 \\
\end{array}$ \\
\hline 暗 & 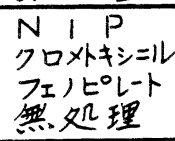 & $\begin{array}{ll}54.28 & (117) \\
59.33 & (128) \\
56.05 & (121) \\
46.17 & (100)\end{array}$ & $\begin{array}{l}65.95 \\
61.83 \\
72.38 \\
47.48 \\
\end{array}$ & $\begin{array}{l}(139) \\
(130) \\
(152) \\
(100)\end{array}$ & $\begin{array}{l}1.21 \\
1.04 \\
1.29 \\
1.03\end{array}$ \\
\hline
\end{tabular}

(52) 


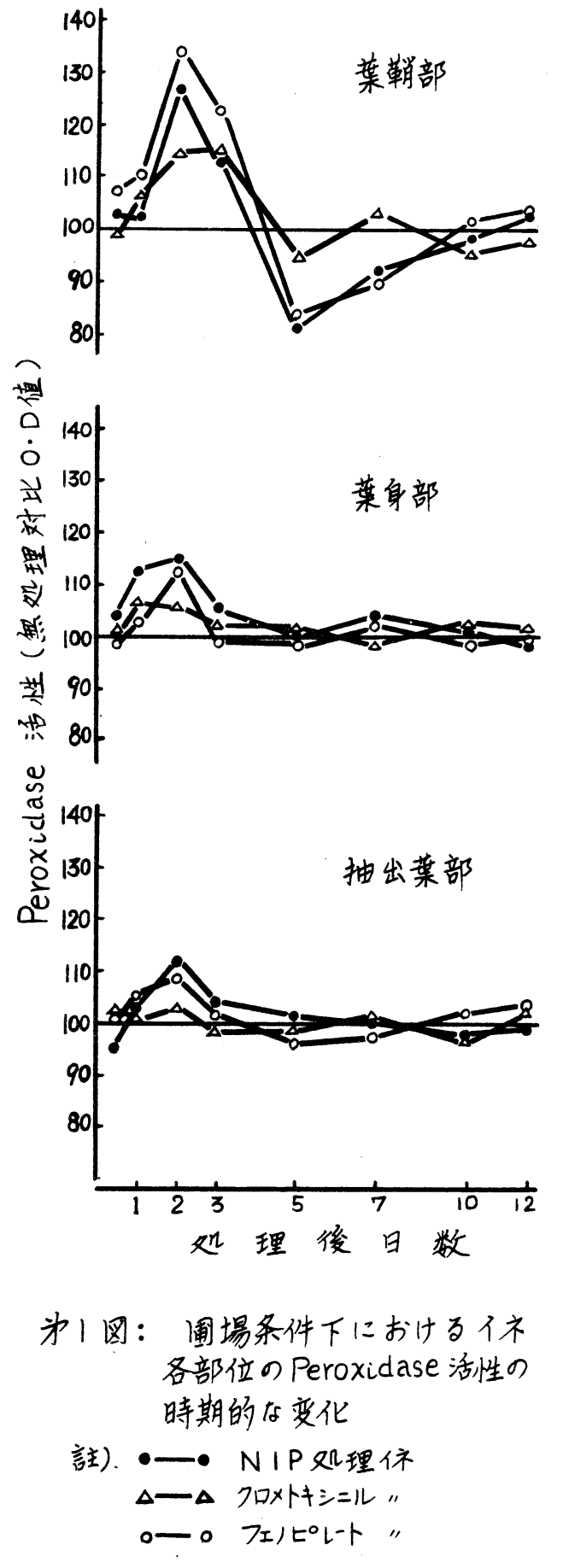

\begin{tabular}{|c|c|c|}
\hline \multirow{2}{*}{ 桼 } & Peroxidase Activity & \multirow[b]{2}{*}{$\%$} \\
\hline & $430 \mathrm{m \mu}$ OPtical-D. $/ 100^{\mathrm{ms} F \cdot W}$ & \\
\hline $\begin{array}{l}N 1 P \\
\text { クロメトキシニル } \\
\text { フェ)ピレート }\end{array}$ & $\begin{array}{l}.430 \\
.410 \\
.455\end{array}$ & $\begin{array}{l}120 \\
115 \\
127\end{array}$ \\
\hline 無処理 & .357 & 100 \\
\hline
\end{tabular}

为了表: Indole Acetic Acid Oxidase 活性

\begin{tabular}{|c|c|c|c|}
\hline \multirow{2}{*}{$\begin{array}{l}\text { 条 } \\
\text { 件 }\end{array}$} & \multirow{2}{*}{ 薬 刘 } & * I.A.A Oxidase Activity & \multirow{2}{*}{$\%$} \\
\hline & & $525^{\mathrm{m} \mu}$ OPtical-Density & \\
\hline 明 & $\begin{array}{l}N \quad P \\
\text { クロxトキシニル } \\
\text { フエル゚レート } \\
\text { 無処理 }\end{array}$ & $\begin{array}{l}.590 \\
.625 \\
.670 \\
.540 \\
\end{array}$ & $\begin{array}{l}110 \\
116 \\
124 \\
100 \\
\end{array}$ \\
\hline 暗 & $\begin{array}{l}N \quad P \\
\text { フロxトキシニル } \\
\text { ᄀエルピレート } \\
\text { 瞴処理 }\end{array}$ & $\begin{array}{l}.470 \\
.480 \\
.530 \\
.390\end{array}$ & $\begin{array}{l}121 \\
123 \\
136 \\
100\end{array}$ \\
\hline
\end{tabular}

为4表: 光の有無と裼变

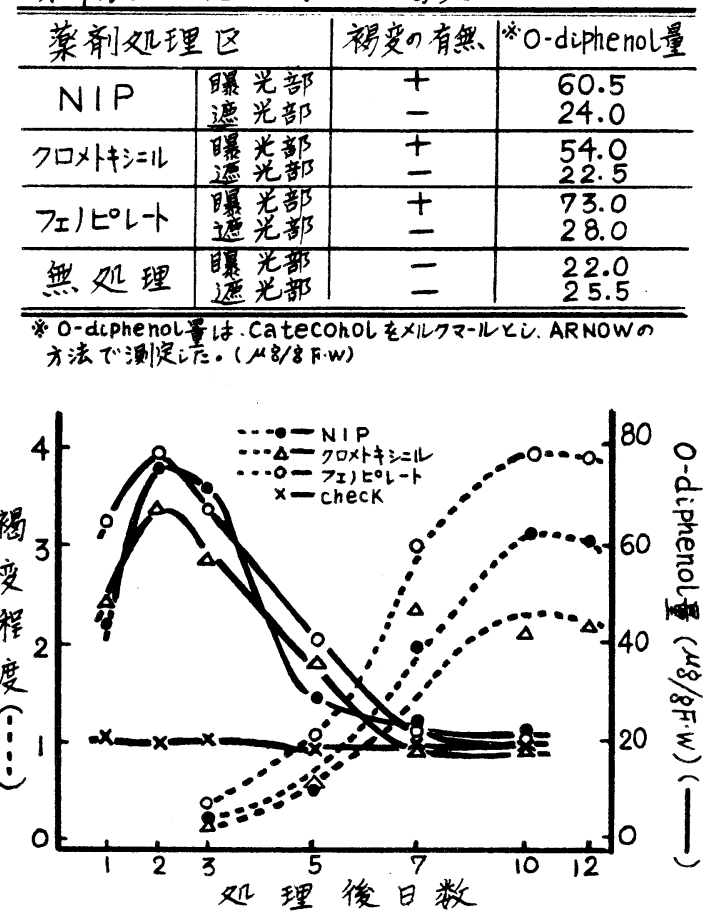

为2四: 褐变の発現消長と体内o-diphenol量の推移 
19. 除草剂による薬害の解析

一一数種除草削による亿不。isozymeの变化——

$$
\text { 楖开功・中村弘(日本装蒋・研) }
$$

近年、曹蔡による作物への蔡害ガ大寺くとりあげられ、除草剂でも選択殺草性の高

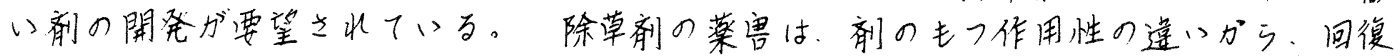

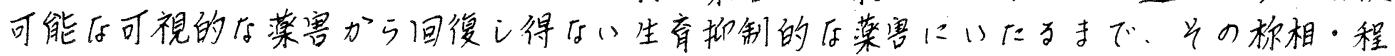

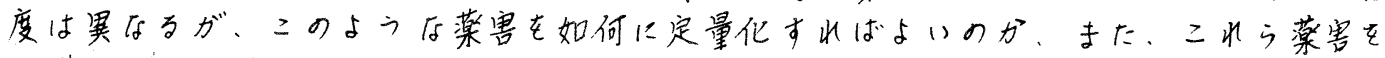
回避できる方策があるのがといつた点は、剂を開発していくうえで重要な課題であり

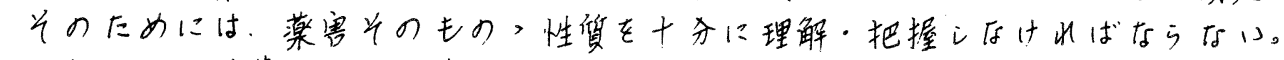

本報では、除草剂による薬害を解浙する手段どて Thin Layer Electrophoresisを用 1)、数種の除草剂:こフいてイネのPeroxidase およびEsterase isozymeの变化々の他を 調ベた。

1)、寒天ゲル薄尼電気泳動法：寒天とPolyvinyl Pyrrolidoneを用いる荻田的の水平式寒 天ゲル泳動法によった。Peroxidase isozymeの检出には、ベンジジン眽酸を、Esterase

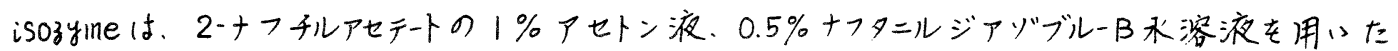

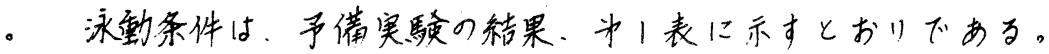

2)、イネの莱令および部位によるisogymeの变化：予めポットで育成レた菜令の累た

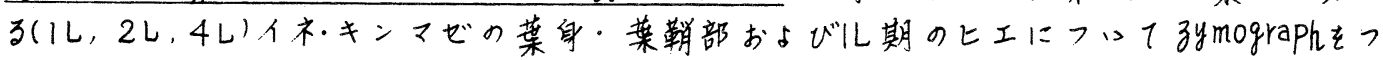
くり、(1).莱令、(2).部位、(3).イネーヒエによるPeroxidase isozyme のPatternを調べた。

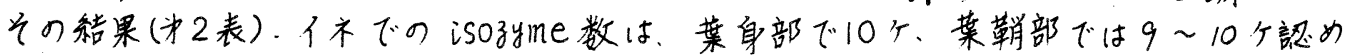

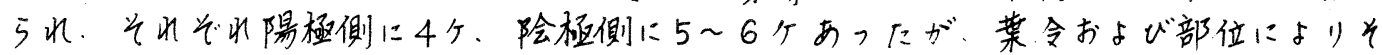

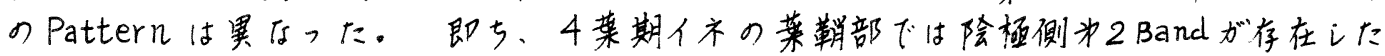
ガ、2 莱期不の莱䩗部位ではそ川ガ認めう北たがった。

また、葉身・葉鞘部位の间では、葉身部で陽極侧の为2、㓌極倒の为 2,6 B a nd の

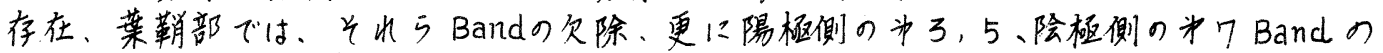
存在が認めうれた。一方、|菜期のヒ工では、同一菜令のイ、皂と比較して、isozyme Patter几は全く異〔るつていた。

このように、菜令あるい:部位でisozyme の Pattern、呈色程度が異なることは、 同一植物乙い之ども、生理的活性ガ異なっていることを示えており、特にるymograph の作成においては、材料調整には十务注意世的ばすらない。

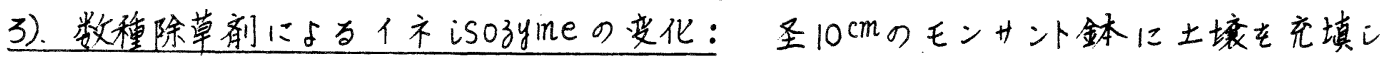

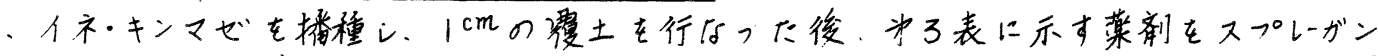

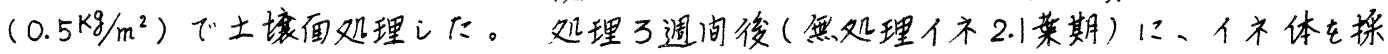
取・磨碎し.Peroxidase およびEsterase の子ymographをつくった。

乡秥果(为了表)、isozyme Patternおよび呈色程度は、剂の作用性の量》で果

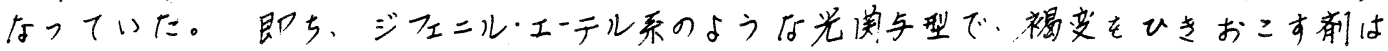


iSozyme のPatter几には变化がないが. 発色が相対的に無処理区よりも強かつた。

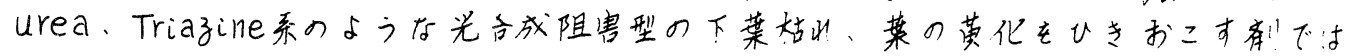
isozyme 数の減小ガみられた。この場吕、発色の程度よりみて、 isozymeが本質

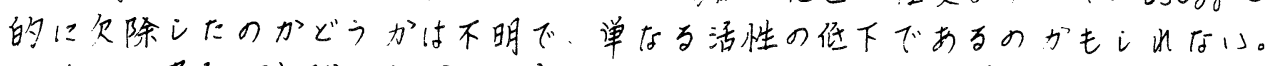

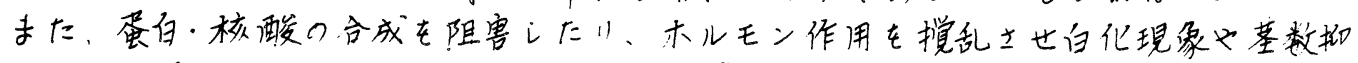
制となって現れるA・T・Aや2・4一D、更に酸化的“燐酸化阻害として知られるPCPなどは、 Peroxidase Esterase zymograph で特異なisozymn出現せ欠除がサられた。

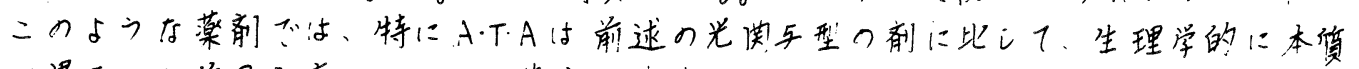

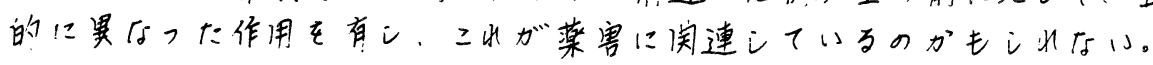

4)、まとめ: Peroxidase, Esterase のisozyme数、乡のPatternおよび呈色の程度

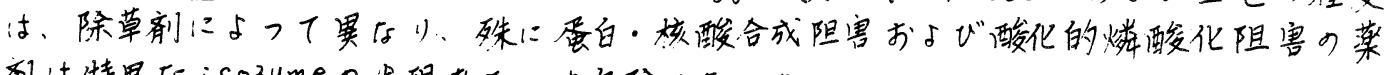
㓩:さ特異厄isozymeの出現おるいは除となった。

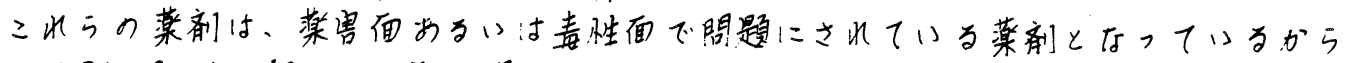

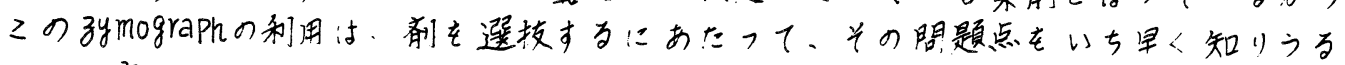
一フの目安にたるであろう。

ともあれ、Peroxidase、Esterase:こ限らず数種の孜mographを組古わせることに よフフ剂のもフ作用性をより的確に予知し、更に莧害の性貨などをより一局解明しう る牛段となるかも林い。

为|表：寒天公ル組成およU゙泳動条件

\begin{tabular}{|c|c|c|c|}
\hline 試料 & $\begin{array}{l}\text { 分離·検出 } \\
\text { isozyme }\end{array}$ & $\begin{array}{l}\text { 寒天ゲル組成 } \\
\text { イオン強度 PH6.8phosphate } 100 \mathrm{~mL} \text { 当りの是 (g) }\end{array}$ & $\frac{\text { 泳動条件 }}{\text { 電壬、電流 時间 }}$ \\
\hline \multirow{2}{*}{$\begin{array}{l}\text { イネ } \\
ヒ エ\end{array}$} & Peroxidase & 0.025 寒天粉末 0.7 , P.V.P. 2.0 & $350^{\bar{\nabla}} 20^{\mathrm{mA}} 90^{\text {分 }}$ \\
\hline & Esterase & 0.025 寒天粉末0.7, P.V.P 2.0 & $350^{\nabla} 18^{\mathrm{mA}} 90^{\text {分 }}$ \\
\hline
\end{tabular}

泳動ガラス板： $12^{\mathrm{cm}} \times 16^{\mathrm{cm}}$

为2表: 菜令・部位によるisozymeの变化

\begin{tabular}{|c|c|c|c|}
\hline 試料 & 部位 & $\begin{array}{c}\text { isozyme } \\
\text { 数 }\end{array}$ & $\frac{\text { * isozyme Band }}{765432101}$ \\
\hline イネ:ル & $\begin{array}{l}L \cdot S \cdot \\
L: B .\end{array}$ & 10 & $1112--4$ \\
\hline \multirow{2}{*}{ イネ:2L } & $L \cdot S \cdot$ & 9 & $1-3-4-4$ \\
\hline & $L \cdot B$ & 10 & $21-4-4-314421-$ \\
\hline \multirow{2}{*}{ 衤:4L } & L.S. & 10 & $1-4-4-4: 31442-1$ \\
\hline & $L \cdot B \cdot$ & 10 & $11-4-4-: 414421-$ \\
\hline EI:IL & 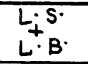 & 12 & $----434: 44222111$ \\
\hline
\end{tabular}

※isozyme Band の数值は、発色の程度を4点法( $4,3,2,1)$ 強尔た
ものである. 


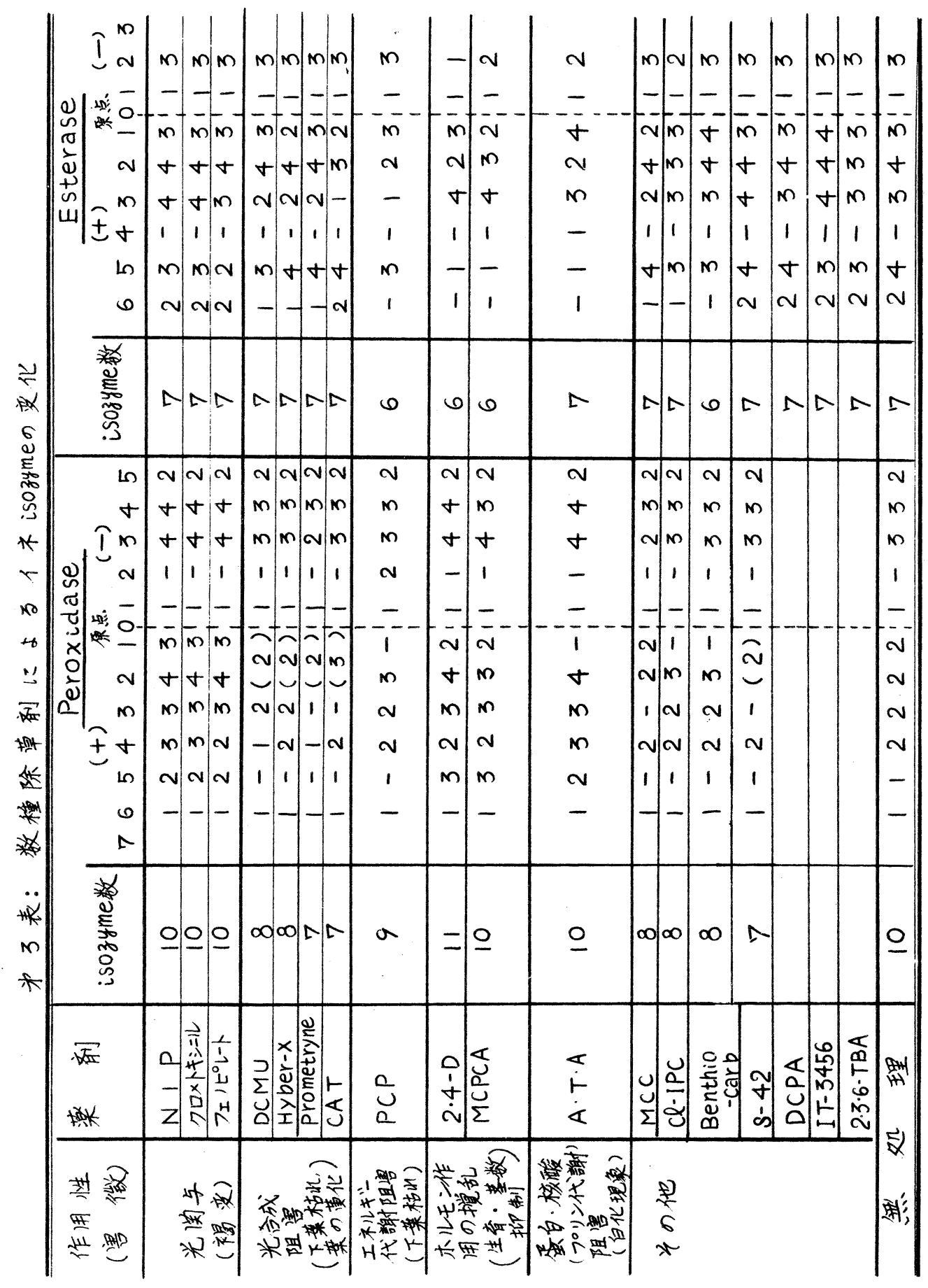


20. フタルイミド系化合物の水田除草刹とは マa特性

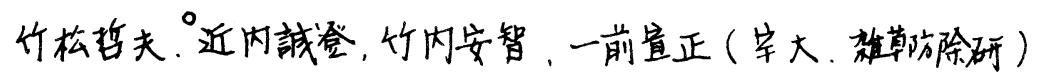

1. 目的

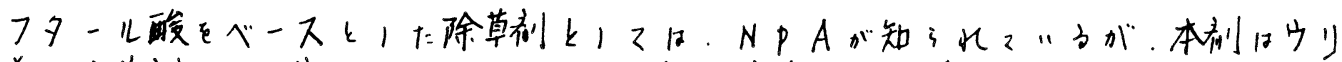

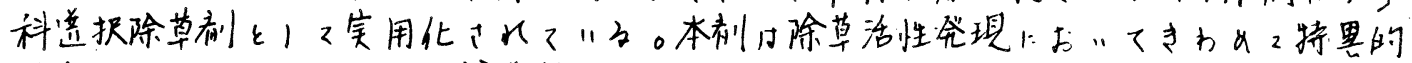

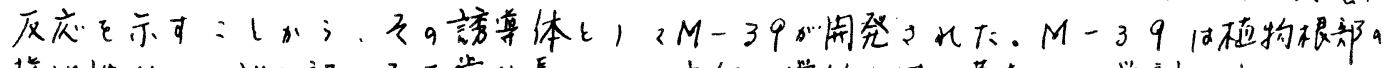

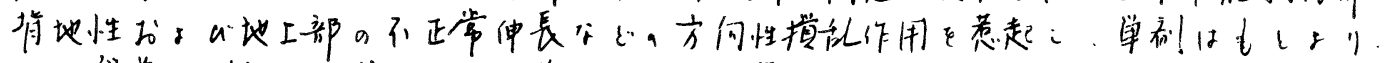

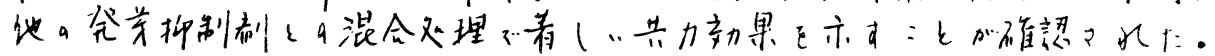

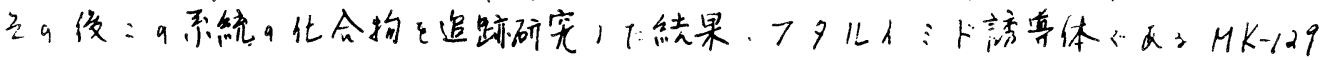

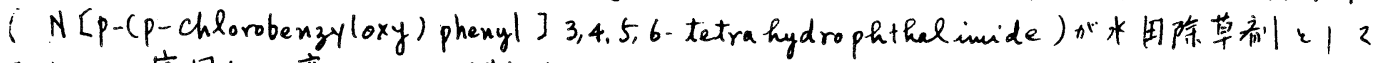

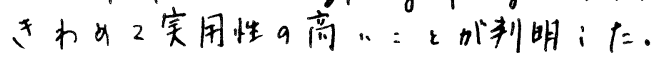

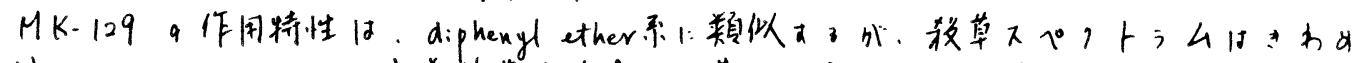

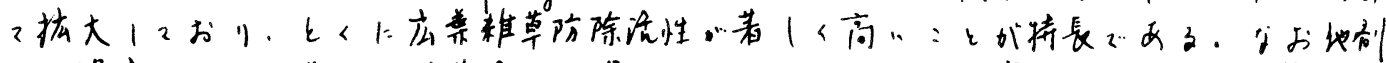

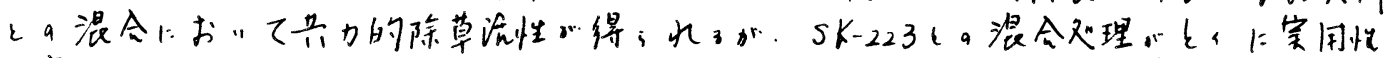

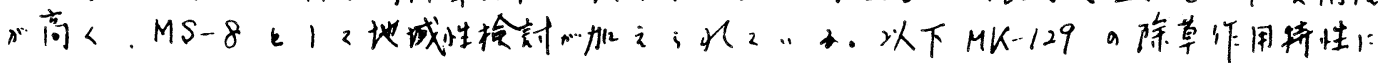
)“湖先才了。

\section{2、实雅方法}

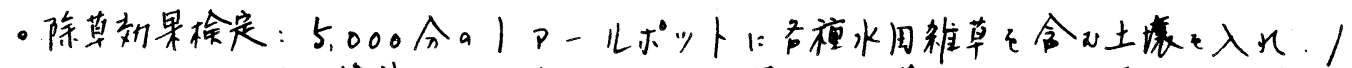

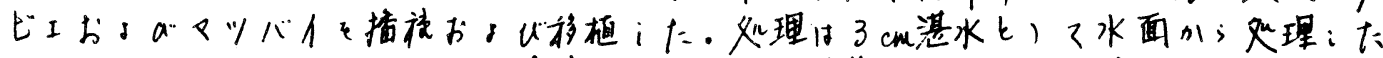

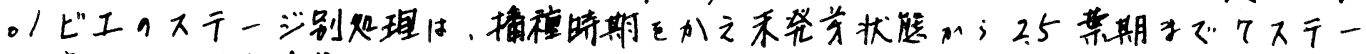

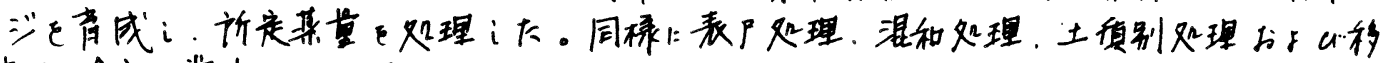

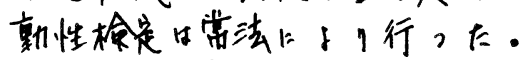

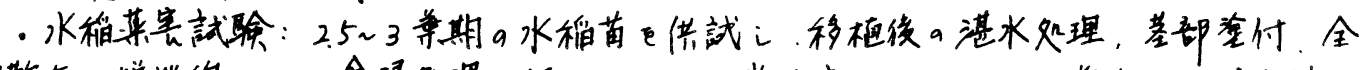

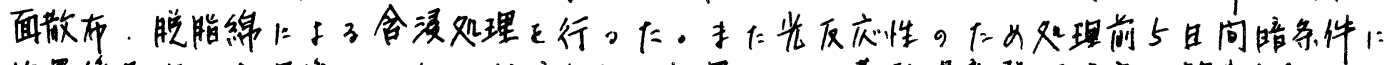

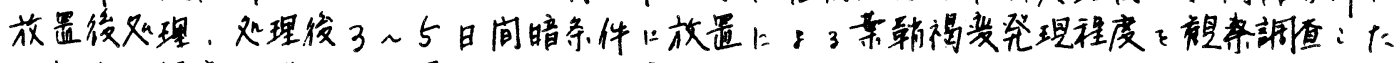

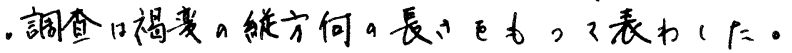

\section{3、結果的时考秦}

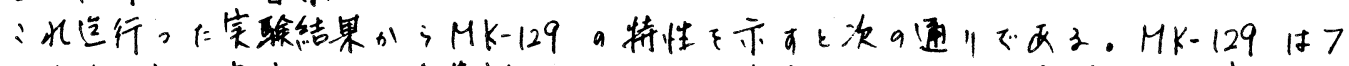
ター儿イ

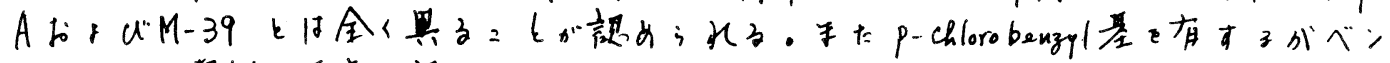

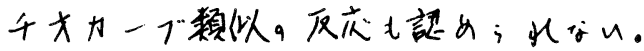

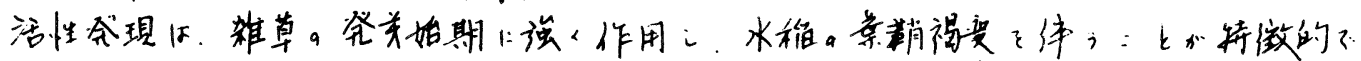

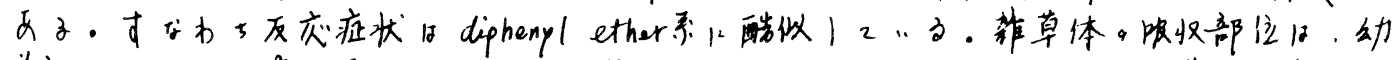

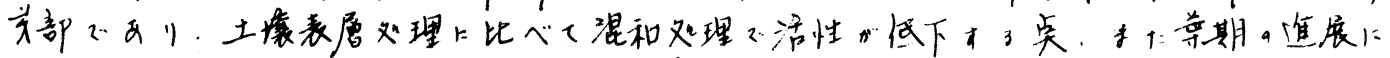

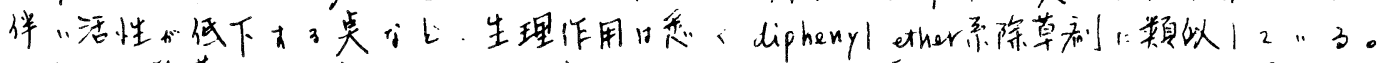

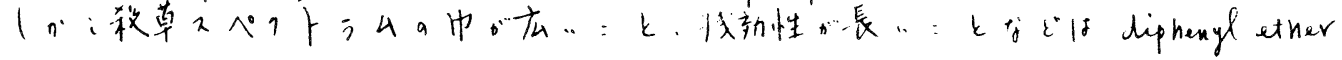




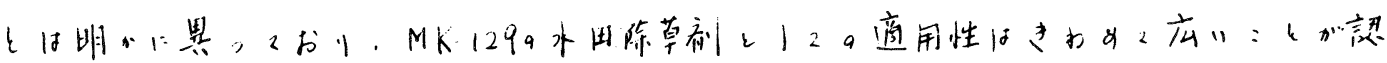

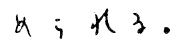

MK- 1299 草福别除草活性中, 表。

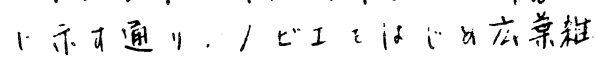

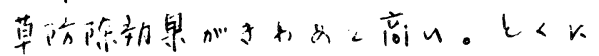

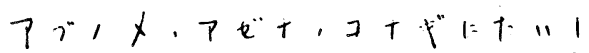

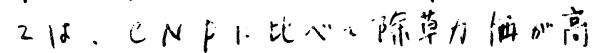
人, 小, 抑草期间心長山。

ノビ工・カメッウ・マッバんにた

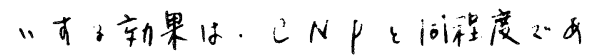

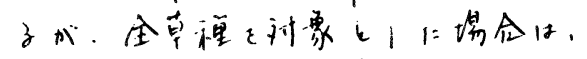
MK-1299隹合的除草力洒12明》1

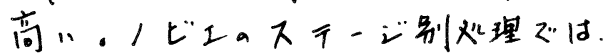

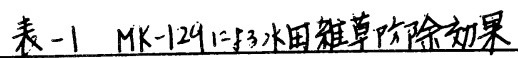

\begin{tabular}{|c|c|c|c|c|c|c|c|c|c|c|}
\hline & $\begin{array}{l}1 \\
1\end{array}$ & $\begin{array}{l}7 \\
n^{7} \\
7 n\end{array}$ & $\begin{array}{l}3 \\
x \\
f^{\prime \prime}\end{array}$ & $\begin{array}{l}\text { H } \\
11 \\
7 \\
+1\end{array}$ & $\begin{array}{l}n \\
x \\
y \\
1\end{array}$ & $\begin{array}{l}7 \\
7 \\
1 \\
x\end{array}$ & $\begin{array}{l}P \\
t^{n} \\
T\end{array}$ & \begin{tabular}{l}
$z$ \\
\cline { 1 - 1 } \\
1 \\
1
\end{tabular} & 济 & $\begin{array}{l}\text { 卓 } \\
\text { 公 } \\
\text { f." }\end{array}$ \\
\hline 20 & 0 & 1 & 0 & 1 & 0 & 0 & 0 & 0 & 1 & 1 \\
\hline 40 & $I$ & 4 & 1 & 2 & 1 & 1 & 2 & 1 & 2 & 2 \\
\hline MK.12960 & 3.5 & 4 & 1.5 & 4 & 2 & 2 & 3 & 1 & 3 & 4 \\
\hline $\mid M k 72$ & 4 & 5 & 3 & 5 & 3 & 3 & 4 & 2 & 5 & 5 \\
\hline 120 & 5 & 5 & 4 & 5 & 5 & 5 & 5 & 3 & 5 & 5 \\
\hline \multirow{5}{*}{$\begin{array}{r}40 \\
60 \\
80 \\
120\end{array}$} & 0 & 0 & 0 & 0 & 0 & 0 & 0 & 0 & 0 & 0 \\
\hline & 1 & 0 & 0 & 0 & 1 & 0 & 0 & 0 & 0 & 0 \\
\hline & 3.5 & 1 & 1 & 2 & 3 & 0 & 1 & 1 & 0 & 1 \\
\hline & 4 & 2 & 1 & 3 & 4 & 2 & 3 & 2 & 2 & 2 \\
\hline & 5 & 2 & 2 & 4 & 5 & 3 & 4 & 3 & 3 & 3 \\
\hline
\end{tabular}

1.5莱期以内、处理2018 MK-129. CNP

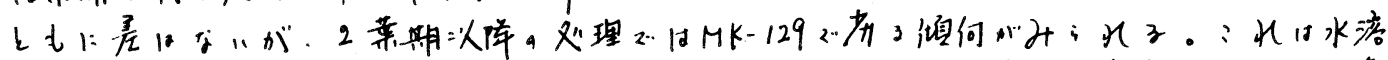

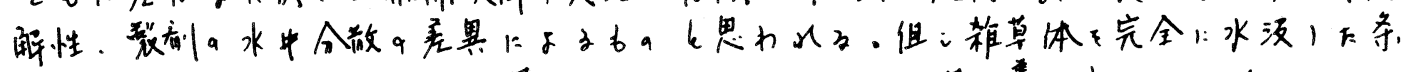

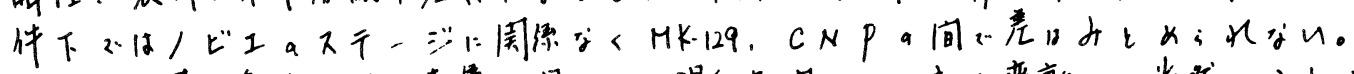

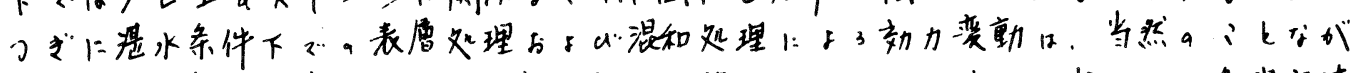

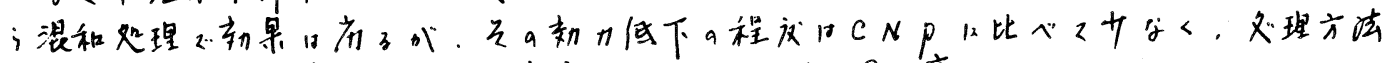

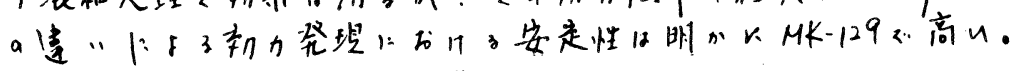

MK-12910他剂上人1: 発弟抑

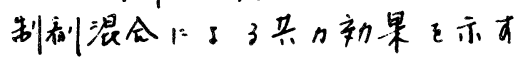

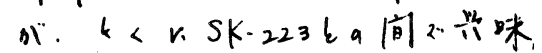

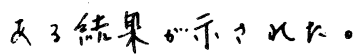

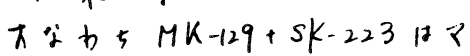

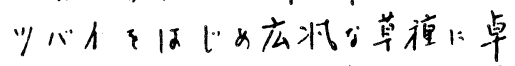

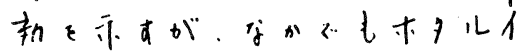

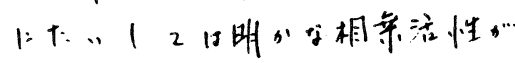

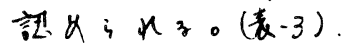

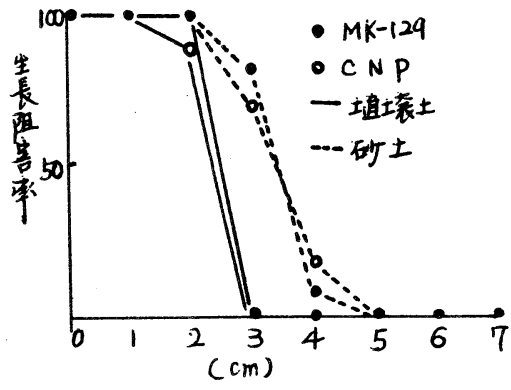

圆-2 MK-1299塔中移动

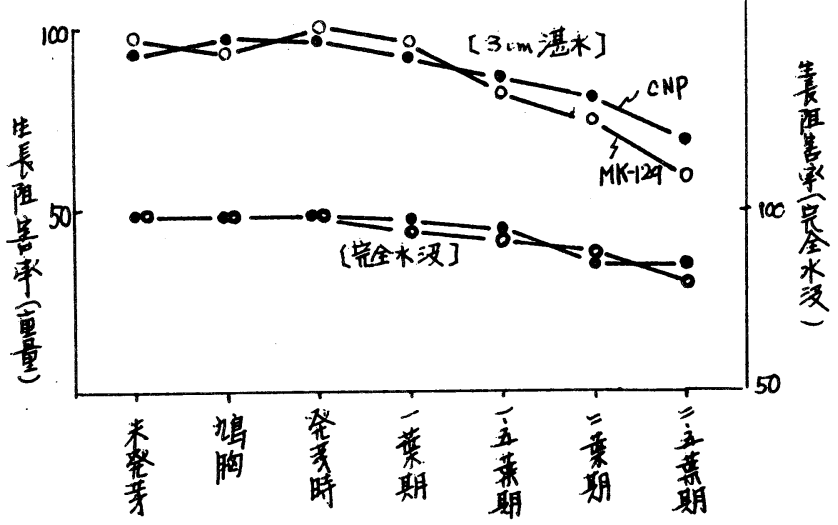

四-1 M K - 129r.53/E゙工 stage别防除动果

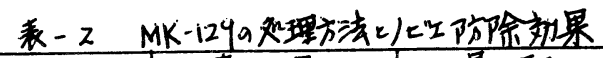

\begin{tabular}{|c|c|c|c|c|c|c|c|c|c|}
\hline & \multicolumn{4}{|c|}{ 要 } & \multicolumn{4}{|c|}{ 混和 } \\
\hline & & 52 & $1(10)$ & $2 i v$ & 400 & 50 & 100 & 200 & 400 \\
\hline \multirow[t]{2}{*}{$M K-124$} & 劫果 & 5 & 5 & 5 & 5 & 3 & 5 & 5 & 5 \\
\hline & 莫荌 & \pm & † & $t$ & $T$ & - & - & - & - \\
\hline \multirow{2}{*}{ CNP } & 初果 & 5 & 5 & 5 & 5 & 2.5 & 3 & 3.5 & 5 \\
\hline & 菜害 & \pm & 上 & + & + & - & - & - & - \\
\hline
\end{tabular}

(58) 


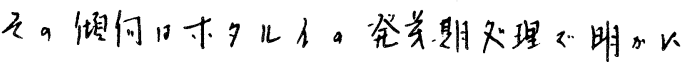
表示K. MK-129 100 150\%/10a. Sk-22370 100\% \%

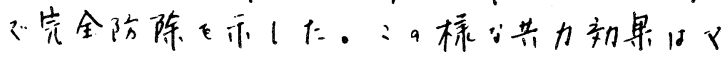

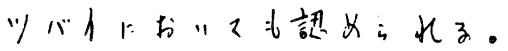

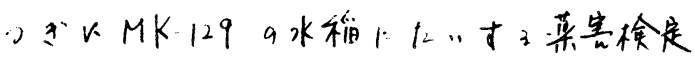

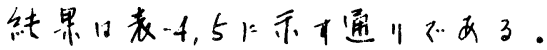

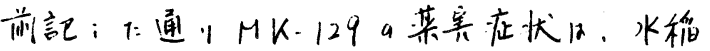

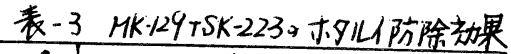

\begin{tabular}{|c|c|}
\hline 9.9. & $\frac{5 K-223}{0}$ \\
\hline 0 & $0012 w$ \\
\hline 25 & 0,254 \\
\hline 50 & 0,34555 \\
\hline & $\begin{array}{llllll}3 & 4 & 5 & 5 & 5 & 5\end{array}$ \\
\hline 150 & 555 \\
\hline
\end{tabular}

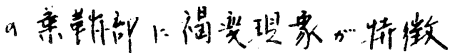
的で・dipheryl cther 系除草

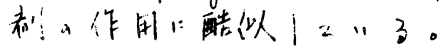

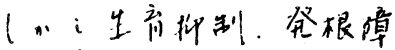

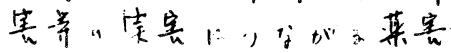

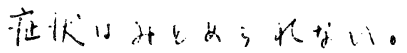

他口袖变症状。示可除草 剂上比較梌是1上结果つ之 $a: x$ : 利明1个。

水榴苗、基部上菜液金付

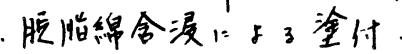
全面散布、紶果、福变、発 瑅程度过 G $315>N 1 P>x-52>$ $C N P=M K-129$, 盢1:大 $<=9712709$ 中心 218

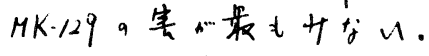

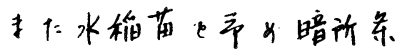
件下1:5日间放是该处理。

表一4 MK-129，只理方法上水稻宾客

\begin{tabular}{|c|c|c|c|c|c|c|c|c|c|c|}
\hline & \multicolumn{3}{|c|}{ 綿瑟付 } & \multicolumn{2}{|c|}{ 声水理理 } & \multicolumn{4}{|c|}{ 墓部全村 } & 全面敬布 \\
\hline & $0.1^{\%}$ & & & & 300 & $0.1^{9}$ & 0.25 & & 1 & 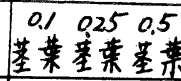 \\
\hline$G-315$ & 1 & 3 & 6 & & 7 & 1 & 2 & 3.5 & 5 & $00 / 214$ \\
\hline$C N P$ & & 95 & 1,5 & & 0.5 & 0 & 0 & 0.5 & 2 & 10000005 \\
\hline NiP & & $z$ & 4 & & 5 & 2 & 4 & 5 & 6 & 010407 \\
\hline$x-52$ & 0.5 & ' & & 2 & 4 & 1,5 & 3 & 4 & 6 & 10000316 \\
\hline$M K-129$ & 0 & 0.5 & 1.5 & 0 & 1 & 0 & 0 & 0.5 & 2 & 100000.00 \\
\hline
\end{tabular}

表中数字は禓严長卢而际

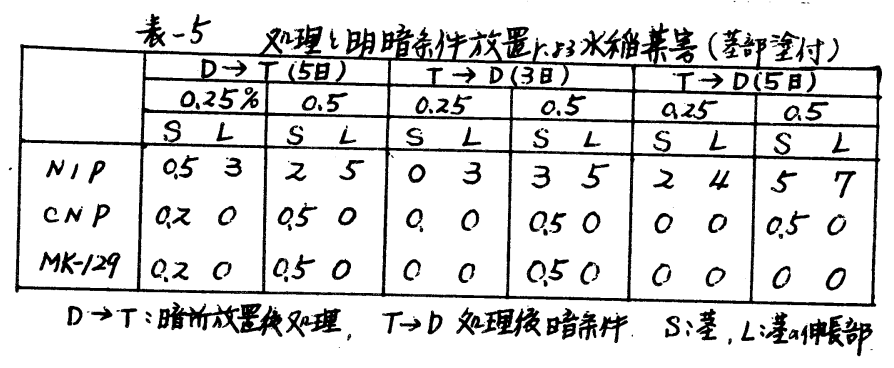

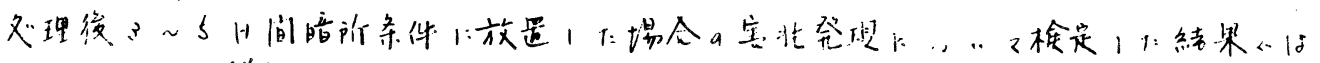

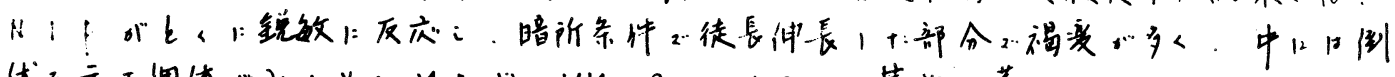

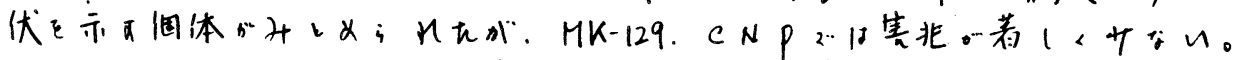

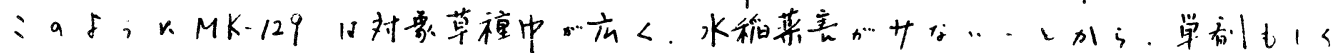

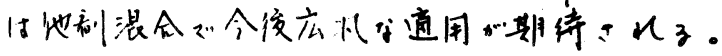


21.オキサジアゾンに橍する研究

1) 水由土壤によるオキサジアジンの吸着性について 河村雄司，小野博(日産化学生物化学研究所)

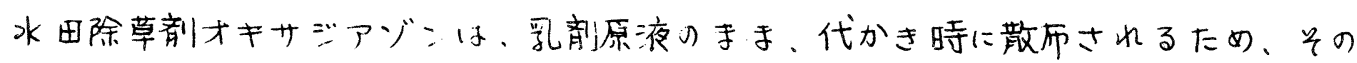

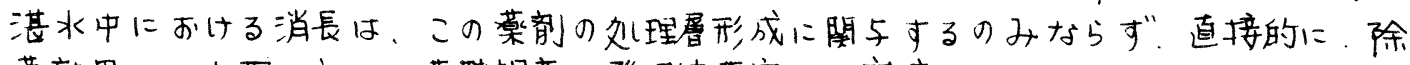

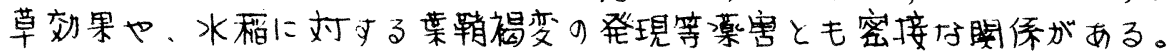

オキサジアゾンの观理後の湛水中濃度の消長に最も大きな影響をかよぼすのは、实 用的には、代かきのどの時期に散布されるかという处理时期や、代かき条件であるが 本奥的には土塆に与る吸着性によると考之ら北る。

そこで、オキサジアゾンの㴖水中濃度を低下させる土㙵による吸着要国を、すず、

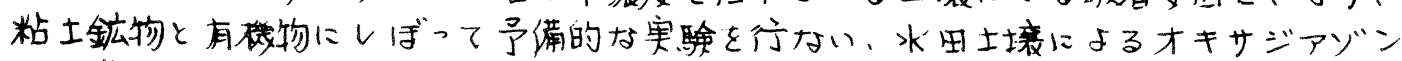
の吸着性と作用性の閔保について基不楚的吅知見を得るうとした。

一実験 オ 法—

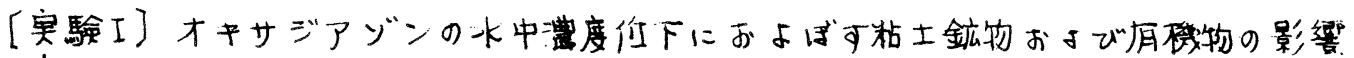

痛植を $2.3 \%$ 含玉冲皘埴土(粘土含量 $57 \%$ ) の風乾細土を b a se に, 所定量のベン

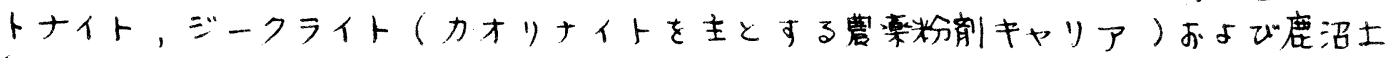

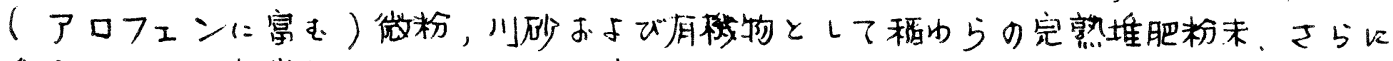
参考のため活性炭粉末を混入した土塞各 $200 \mathrm{~g}$ を内径 $9.5 \mathrm{~cm}$ 深さ約 $9 \mathrm{~cm}$ の深店三

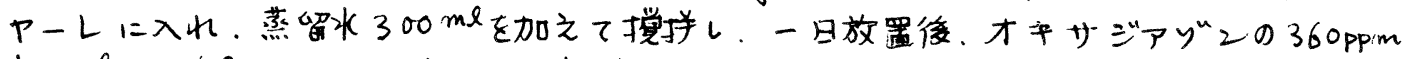

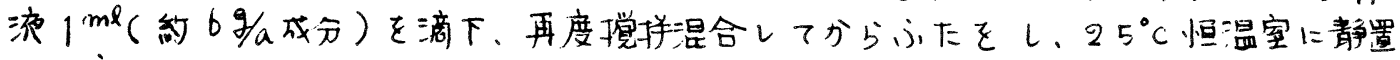
一定时間淩に各三ャーレの表面水5 . m l を採取して、n一へキサンで抽出、GLC ぞ分析し、水中湱度を算出L下。( 3 反覆)

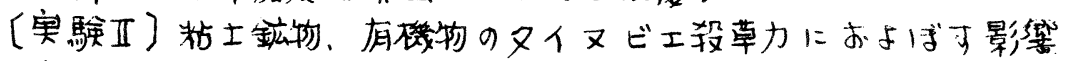

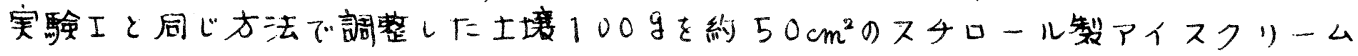

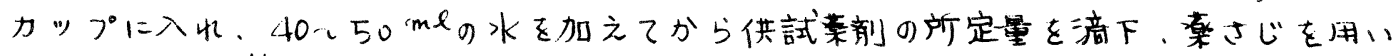

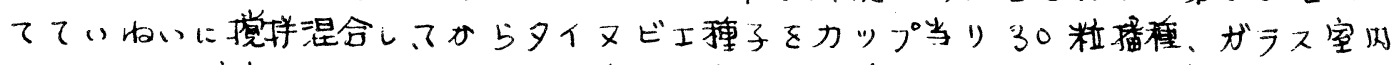
で18 日成栽培してから地上部生体重を测定、各士境における煞草力の差を比較した。 一突験結果ふむひ存察—

本実験に供試した冲榡埴土の粘士鉱物は、心゙ーミュキライト，イライトおよびカオ リンを主とし、火山灰の混により若干量のアロフェンを含むと推定さ水る土壤(農 技研瓷粦より)である。表一にに見られる如く、モンモリロナイトを主とする゙゙ントナ イト，カオリナイトを主とするジークライトおよびアロフェ:を大量に含む鹿沼上を

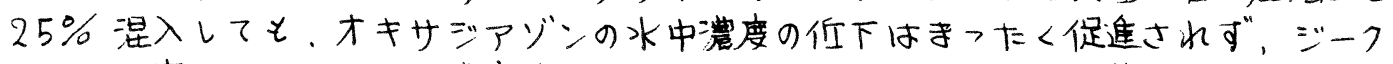
ライトや震沼土ではむしろ漕度任下が卯えら水了倾向が見られ、吸着能をも下ない川 砂を添加した場合と差が認められなかった。

これらの結果は、オキザジアゾンが少榇ともジークライトや鹿沼土にははとんど 吸着されず、ベントナイトの吸着能も兰う大きいものではないことを示すものである。

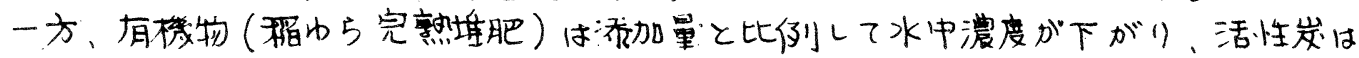
$1 \%$ の稆で、水中からオキサジアゾーが検出されず、いずれも強い吸着能のあるこ 
とが認められた。

己丸ら粘土鉝物也、有機物を㳢加さ山た土校にホける除草刘の殺草力は、国1几4

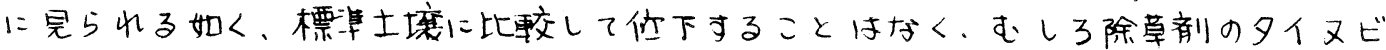

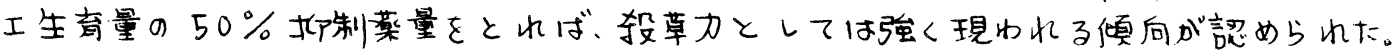

しかし表一2に見られるように、各条件の無㞦理区の夕イ代エの生育量には大差 があるてと、また、タイ又ビエの生充がほとんど、あるいは完全に抑制される萖量に

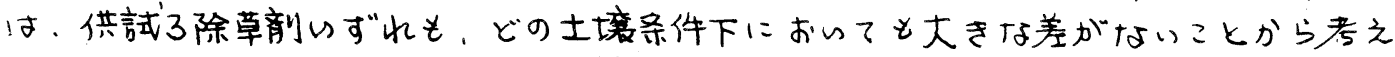
て、生当量の50\%耶利量をもつて土壇間の轧草力を比較することは必らずしも適当で きけいと考えられる。

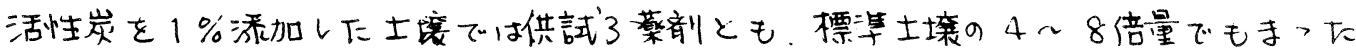

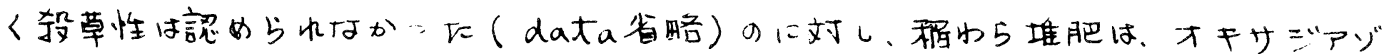

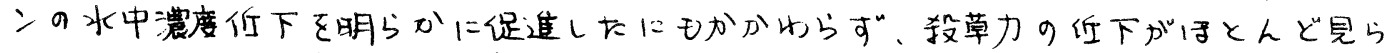
杖かつたてとは害用的には重要な意味をもつている。

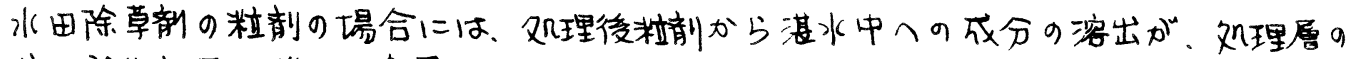
形成也除草珓果の登現に重要であるのに村し、オキサジアゾンの特殊た施用法では、 湛水中から土埣への成分の速やかな移動が効果や荣害を安定きせる最大の要因である。

こ炕らの䒠験結果から，道らに䒠際の水田における粘士や有䂝物と除草绪の作用性 との閏柔を論ずるてとは問題であるが、オキサジアン゙ンに閶してね、少なくとも、瘦

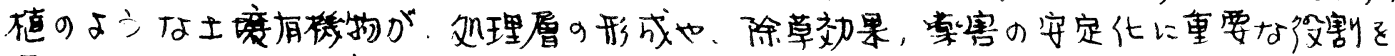
果しているものと推察される。

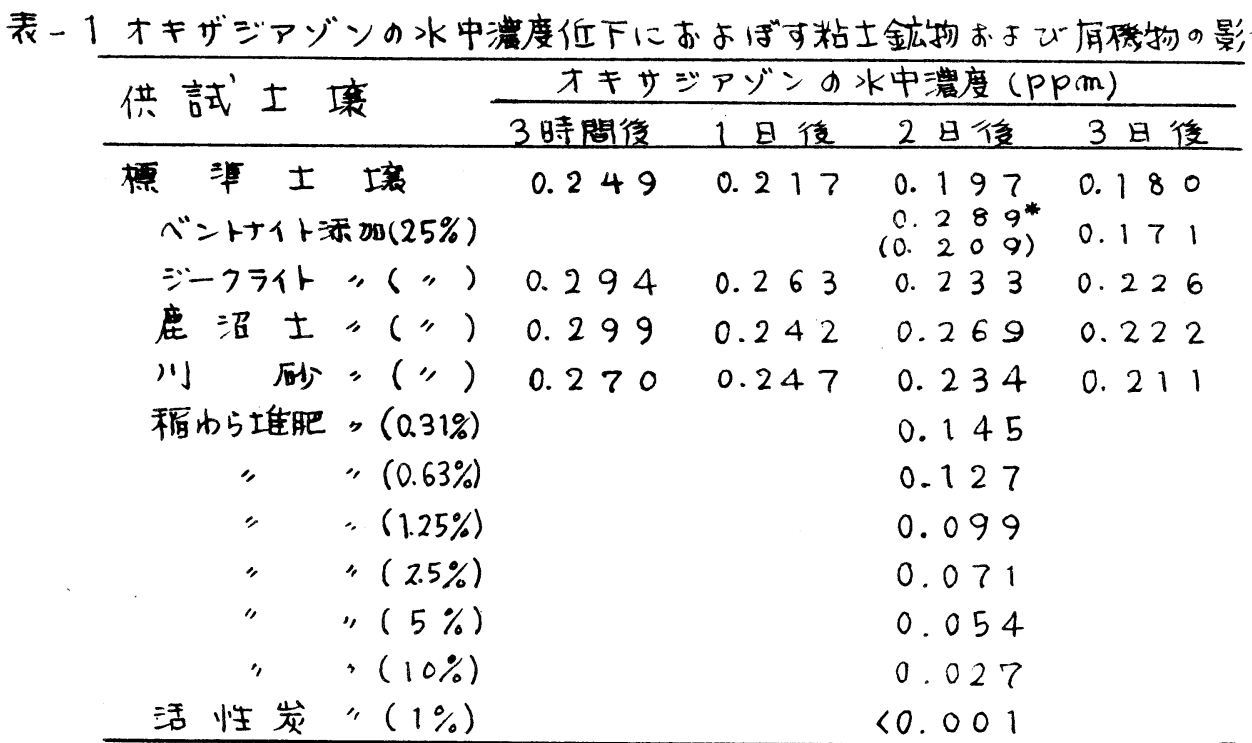

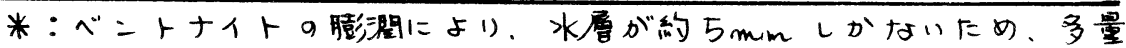

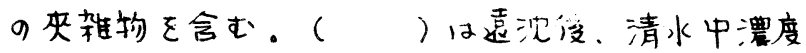


土坮条件とオキサジアゾーのタイヌビエ轧草力
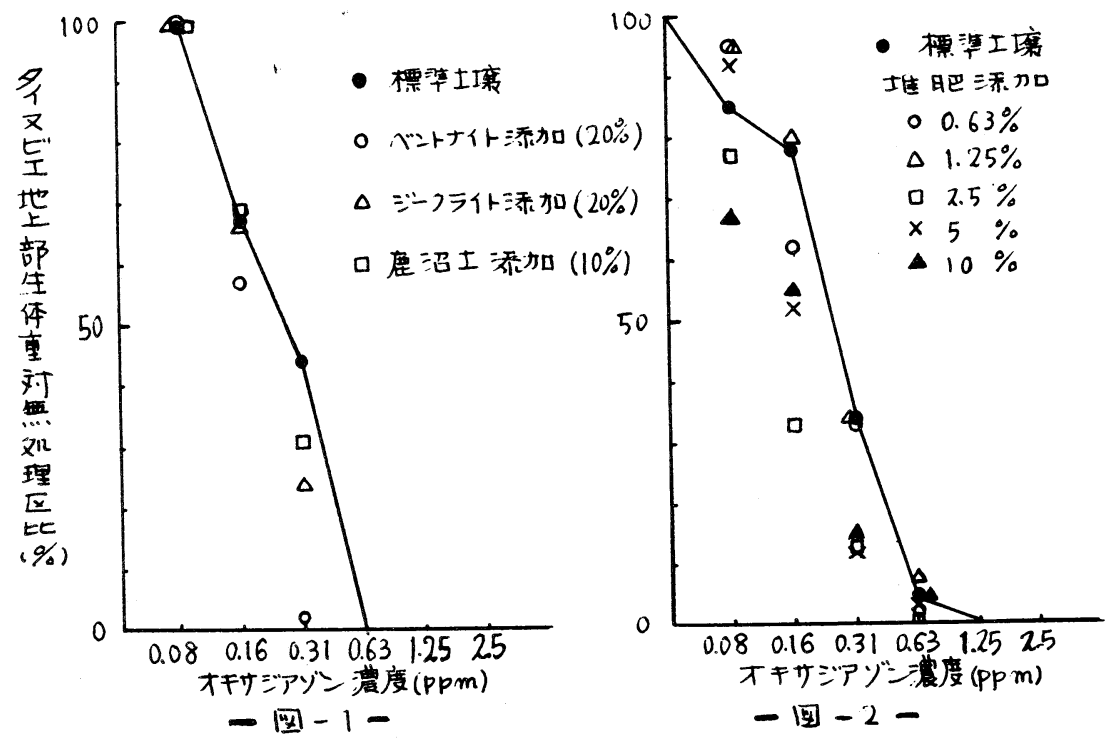

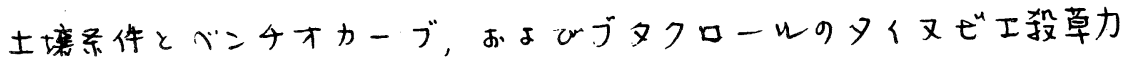

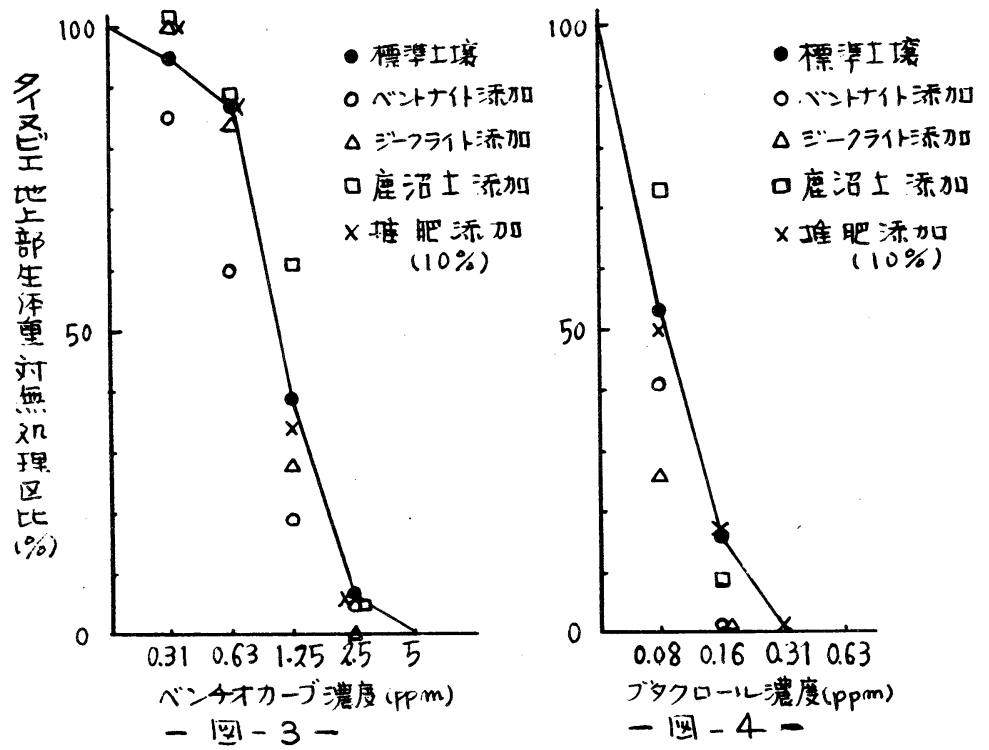

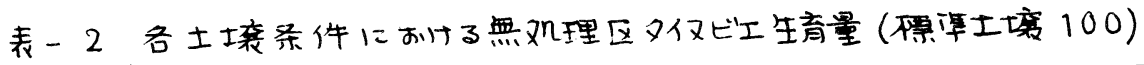

\begin{tabular}{|c|c|c|c|c|c|c|c|c|}
\hline \multicolumn{3}{|c|}{ ベントナイト添版 (20\%) } & 108 & 堆 & 肥 & 添加 & $(1.25 \%)$ & 122 \\
\hline ジークライ & $r$ & $"(")$ & 93 & & $"$ & & $(2.5 \%)$ & 191 \\
\hline 庞沼 & \pm & $"(10 \%)$ & 56 & & $"$ & & $(5 \%)$ & 240 \\
\hline 堆 & 肥 & $=(0.63 \%)$ & 111 & & " & & $(10 \%)$ & 277 \\
\hline
\end{tabular}

